Gabriela Cretu

\title{
Romania: the cost of scarce social policies - economic failure
}

\begin{abstract}
This article questions the supposed efficiency and equity trade-off, presenting the Romanian case as an illustration of its failure. Scarce social policies have not made the Romanian economy more efficient; on the contrary, they have contributed to reducing productivity and speeding up recession, endangering the future long-term development of the country. Romanian social indicators are worrying: poverty is high; inequalities are growing; people's trust in institutions, in each other and in the future has reached its lowest level ever; and migration has been the solution chosen by many to overcome the difficulties of transition. Meanwhile, the domestic labour market faces penury of skilled labour in many sectors, in spite of really high unemployment, while the education system is suffering a deterioration in terms of quality and credibility. Far from being a solution, the recent measures taken by the government to reduce the deficit and balance the public budget will negatively affect the economy and retard the possibility of a more equitable society.
\end{abstract}

Keywords: EU accession, austerity measures, social justice, public sector, inequality, poverty, market liberalism, the working poor, minimum income, unemployment, restructuring, labour migration, remittances, employment protection, role of education

\section{Introduction}

Romania, with a population of $21.5 \mathrm{~m}$ people and an area of $238391 \mathrm{~km}^{2}$, is the second largest country in central and eastern Europe and the seventh largest country among the 27 member states of the European Union. Currently, Romania has to secure quite a long external border of the EU with the neighbouring countries of Moldova, Serbia and Ukraine, as well as the Black Sea; the other neighbours are Bulgaria and Hungary. București, with more than two million inhabitants, is the capital city as well as the industrial, cultural and financial centre of the country.

The events that have changed the direction of recent Romanian history are, without doubt, the revolution of 1989 and Romania's accession to NATO and the EU. After the fall of the totalitarian regime, the country decided to join the western organisations and has finally succeeded in doing so: in 2004, Romania became a member of NATO and then joined the EU on 1 January 2007, following the completion of negotiations in 2004 and the signing of the Accession Treaty in 2005.

The prospect of becoming an EU member constituted, for more than a decade, a solid external incentive for the transformation of the country throughout its transition, and offered a concrete target and coherence for political measures. For the population, 
many of these measures were harsh, as they meant: the loss of jobs; the closure of economic activities; and the introduction of different rules than those which people were used to. Additionally, the restructuring of the economy turned into a synonym for firing employees. The opportunity cost of change was high. A study by The Economist estimates:

Assuming, generously, future regional growth of 4-5\% a year, it would take another decade for the transition to have been economically 'worth it'.

Despite these difficulties, there was huge support for accession to the EU: indeed, Romania registered the highest percentage of pro-European citizens. For Romanians, as for many others, joining the EU was the equivalent to a better quality of life, more and better jobs, freedom of movement, the feeling of participating in important decisions and playing a political role; their expectations were high.

However, accession to the Union and the adoption of European standards was neither the beginning nor the end of the integration process; sustained efforts have been needed in many fields to ensure real, as well as nominal, convergence with the EU. Attempts to speed up the processes of integration were, unfortunately, undermined by many factors, and disillusionment after accession was even greater than the hopefulness that had preceded it.

In 2009, after eight years of economic growth and the reduction of absolute poverty, the shockwave of the global economic and financial crisis exposed the imbalances and economic vulnerabilities of Romania. The government decided to ask for the support of the international financial organisations. The International Monetary Fund, the European Commission and the World Bank agreed to cushion the effects of the sharp drop in capital inflows, while addressing Romania's external and fiscal imbalances and strengthening the financial sector with a package which totalled $€ 19.95 \mathrm{bn}$ over the 2009-2010 period. The multilateral support programme seeks to:

- strengthen fiscal policy

- maintain an adequate capitalisation of the banks as well as liquidity in domestic financial markets

- reduce inflation

- secure external financing and improve confidence.

Nothing about economic recovery, or how to face social problems during the crisis, was negotiated in the agreement. The consequence is that Romania currently faces the difficult task of reconciling the conditionality of short-term fiscal consolidation with the need to mitigate the social costs of the crisis and to restore the sources of sustainable and equitable growth. Success in mitigating the impact of the crisis depends on the commitment of the political establishment and the capacity of public sector institutions to work together and to mobilise key stakeholders and the population behind them; recovery also depends on public expenditure. Unfortunately, after the 2007 achievements, no other socially or politically significant goal has come to replace accession to the EU as a unifying national effort: suffering, if it is the case, must have a sensibility. Moreover, austerity measures are working against an economic upturn. 
Recently, in order to control the budgetary deficit, the government decided to reduce all public sector wages by $25 \%$ and to increase VAT from $19 \%$ to $24 \%$. These are the harshest measures taken by a European member state; no other, including those in a very difficult financial situation, such as Greece, have gone as far. Hard times lie ahead!

\section{The case of the trade-off in social policies}

Romania is not yet a welfare state, in spite of accession to the richest 'club' in the world and the big expectations of the Romanian population; on the contrary, current economic and social data show a deterioration of the situation due to the recent crisis and the many difficulties of integration. This statement is necessary because the background to the trade-off between economic efficiency and equity is related to a dispute that commonly takes place in the functioning of welfare states.

As far as this alleged trade-off is concerned, we consider, as many have already shown, that it is based on a short-sighted understanding of economic mechanisms; there are both theoretical and empirical arguments against it (Fouarge, 2003). With no further debate in this respect, we have to underscore a fact: its supporters cannot use any statistical data as confirmation of an ideology referring to an efficiency-equity 'trade-off'; on the contrary, the facts prove that the most equitable societies have built strong and healthy economies and have even succeeded in overcoming the current crisis more easily and more quickly than others; the Nordic European countries being a relevant example.

Nevertheless, the theory is very influential in Romania; one of the biggest debates in latter years concerns the so-called dimension of the state, which seems to be too 'fat', undermining the 'real economy'; this is the specific manner in which this topic is dealt with. Many public decisions nowadays are based on the hypothesis that the state is too big because of social expenditure (the poor consume too much public money) and because the state is too involved in society as a whole (taxation is especially construed as endangering the private sector).

The facts do not support these allegations; efficiency is not low because of too much care for equity but because of hardly any concern in this respect. Total government revenue has been, during the period, around $30 \%$ of GDP, placing the state in the lowest rank in the European Union for capacity of intervention; this indicator shows that Romania is a weak state, not a strong one. The current structure of GDP $(70 \%$ private revenue; $30 \%$ government revenue) is undermining not only as regards the development of social programmes, but also as regards investment in public services and other economic activities of general interest.

In our analysis, equity can go hand-in-hand with greater efficiency. In other words, a generous level of social protection does not necessarily lead to inferior economic results. On the contrary, social policies based on investment in human and social capital are conducive to higher economic efficiency, since they improve the productivity and the quality of the labour force. Social policy is, therefore, a productive factor, even though its costs are generally visible in the short-term while its benefits are often only apparent in the long-term. The lack of coherent social policies and a low level of social spending put economic development at risk and create, or preserve, third world models of development based on a 'cheap' labour force, the export of raw materials and high 
dependencies on foreign capital movement and external markets. A 'cheap' labour force does not mean having lower costs; the prices for goods and services are, as a consequence of liberalisation, more or less similar to other European countries; 'cheap' means only being paid worse. Romanian governments have made such a choice.

Of course, which policies are needed and how much public involvement is considered necessary are political choices; the 'optimal policy' assessment comes from value judgments; but, surprisingly, when speaking about social policies among these judgments, we still notice the notion that wealthy people are wealthy because of their intrinsic merits and that social policies rely on the latter's generosity, proving their concern for social justice.

Far from being an expression of the generosity of wealthy people or governments, social benefits are the result of the moral and ethical choices made in many of our European societies as well as within a few other non-European countries; economic and ethical points of view cannot be separated, being tightly connected, and, as a consequence, the economic order cannot in itself be disconnected from the social and political order. In this context, inequality is a subject with moral, economic and political implications; it is not at all a 'social issue' that wealthy people try to deal with for philanthropic reasons or that the government should only take into account if there are extra budgetary resources remaining.

In this conceptual framework, the real problem is not 'How to lessen the trade-offs'; the real issue is 'How to describe reality in appropriate terms in order to uncover the real problems we face' and to draft the most suitable policies; it indicates an awareness of the reality that economic activities are created to provide people with goods and services, as a means for general human development; it rejects the idea, frequent among economists, that people are born to provide companies with a labour force.

The assessment of any economic system is based on two criteria - efficiency and equity; John Rawls, an outstanding theoretical reference for this topic, says explicitly that we have to give priority to the reduction of poverty in the case of a contradiction between poverty and efficiency. Unfortunately, he also offers legitimacy to larger and larger income gaps; actually, any gap may be justified on condition that it improves the situation of the poorest even a little. In practice, we are aware that the first criterion has always been considered while the second is often forgotten; a few new European member states could be used as an example of this amnesia, Romania among them.

Political decisions are increasingly based on economic science and economic interests. It seems natural for economics to play such a role, but it is not. On the one hand, politics has to deal with people, and human beings are not a commodity like any other, not being subject to the same rules of supply and demand - if such rules exist at all. On the other hand, economics tries to find an optimal use for limited resources. There is nothing wrong with these definitions, except that they are only theoretically valid. Practically, as has already been proven many times by now, economics is not at all a natural science and, in fact, different economic theories seek to justify different ethical choices. Despite this difficult relationship between economics and politics, a large number of sociological studies in Romania have already revealed, especially during the last decade, that public opinion has cut the Gordian knot and very much approves 
of two sentences: economics is true; politics is bad, including social policies... This kind of thinking could be a part of the explanation for the current social conditions.

After the fall of the totalitarian regime in 1989, its economic and political ideology was immediately replaced by the neo-liberal theory of free markets; attempts to introduce the social market economy as a model for Romania's future development were unsuccessful; the free market was conceived as a universal rule for the allocation of economic resources and results and, in a strange way, for social relations and human lives as well. From the moderate left to the right (the left no longer exists in Romania), politicians adopted the discourse of free markets, setting up and following related goals - free trade; less state intervention; the privatisation of public services and companies; deregulation; and freedom of movement for everything - capital, goods, services, labour, etc. The international organisations offered good marks and support for the priests of the new religion; while 'the market says', 'the market can', 'the market regulates itself' and, especially, 'the market is efficient' were considered undoubtedly true statements. Neither accession to the European Union nor the reality of the many losers changed that attitude. Almost no-one took seriously enough the problem of the market's collateral victims - except the victims themselves... There was an excessively optimistic approach towards the future and a lack of critical thinking about social sciences. Or, a less human social environment renders many interventions ineffective, even though they take place; this is the case in Romania where the transition has turned money into a core value and competition without minimal ethical standards into a rule.

Based on such an approach, it has often been said that the transition from socialism to a free market economy has been among the most peaceful revolutions in history. This is certainly not true for Romania; the well-known bloody events of December 1989 are not the only proof. There has also been a largely unseen death toll; as in most eastern European countries, the mortality rate has increased after 1989; meanwhile, life expectancy at birth has declined, especially for men; while many fewer births and an outsized migration have also contributed to the current disturbing demographic situation. ${ }^{1}$ Such demographic changes are clear indicators of a society in extreme stress and have been observed previously only in wartime. Such a reaction from society is not unexpected as long as 'the laws of competition' are seen as some kind of "law of the jungle' in which the strongest is allowed to take everything and the less powerful feels ever more insecure.

If the goal of greater economic efficiency has implicitly been the reason for all these painful changes, even if it has not been achieved, then the other ideal, of greater social justice, has only rarely been present when drafting policies and taking decisions.

As far as equity is concerned, at least three aspects are important when evaluating the country's situation:

a) whether those with equal incomes pay the same level of tax and have similar advantages

b) whether those who have more, pay more

c) whether we have a correct distribution of results.

1 Source - World Bank data. 
Certainly, the means used to achieve a more equitable society are variable, as is the manner of assessing the results of intervention; unfortunately, often, they are not the most suitable. In spite of this variability and freedom to choose, a fact has to be taken into consideration - not only 'specific' social policies have social effects; fiscal or monetary policies may, equally, have direct effects.

In Romania, the progressive taxation system in force was replaced in 2005 by a flat tax rate of $16 \%$; the first concrete social result was a deepening of inequalities. Inequality of income distribution (the Gini coefficient) has increased in just a few years of application from 36.3 (in 2004) to 37.8 (in 2007); for a clearer image of the situation, in most European member states, this coefficient varies between 23 and 30 . The other indicator measuring the inequality of income distribution (the S80/S20 income quintile share ratio) shows the same evolution/involution - it was seven in 2008, after achieving a level of 7.8 in 2007, the highest in the European Union; the average indicator for the EU-27 is five. ${ }^{2}$

Rich people have become richer and poor people poorer than they were before. Immediately after the December 1989 events, a period of economic decline began and lasted until 1992; GDP lost more than $40 \%$. The situation began to improve slightly afterwards, but poverty deepened once again between 1997 and 1999. At the beginning of 2000, the number of poor people had grown by four times compared to the 1989 number: $35.9 \%$ of the population lived in absolute poverty in 2000 . The period between 2000 and 2008 was one of continuous economic growth. In spite of this rapid growth in GDP, however, the country was characterised by a slightly increasing level of those earning less than $€ 1.17$ per hour, the current calculated threshold.

In 2000 , using relative poverty as a measure, $17 \%$ of the Romanian population was poor. According to official governmental data, ${ }^{3}$ after seven years of growth, $18.5 \%$ of Romanian citizens were living below the poverty threshold, while a small gender gap may be registered (18.3\% of male citizens, and $18.8 \%$ of women, are poor). The dominant groups among the poor are:

a) single people, at any category of age but with a larger representation of elderly singles

b) single parent families

c) families with more than three children.

Some $70 \%$ of poor people live in rural areas. The unemployed, pensioners and those working on their own account are more likely to live in poverty than other categories. The north-eastern and southern regions of the country face the problem the most. The ethnic group that is most affected by poverty is the Roma population; up to $70 \%$ of them live in poverty.

There is another fact that is more worrying than poverty itself; Romanian society is characterised by a large category of the 'working poor'. Many 'full-time activity' employees and self-employed workers fall into this category. In Romania - as in Europe, generally - it is typical to think of 'the poor' as non-working people; a poor person is thought to be jobless, a pensioner, a child in a large family, or someone whose ability

2 Source - Eurostat data.

32007 data from INS. 
to work is restricted because of reasons related to their personal capacity (having disabilities) or social responsibilities (being a single parent). In contrast to this general opinion, various studies (Peña-Casas and Latta, 2004; European Commission, 2008; and, regarding the extreme poor in Romania, Stanculescu and Berevoescu (Eds.), 2004) have shown that a substantial share of the poor are in work and that the majority of the poor in Europe live in households in which there is at least one household member who is working.

Romanian national statistics do not include studies on the extent and characteristics of the working poor. It is estimated that more than two million people in the Romanian economy are working in, and living on, subsistence agriculture and can therefore be termed as 'working poor'. The phenomenon began to increase rapidly in 2009, when Romania entered recession and poverty reached $23.5 \%$; this rising trend was maintained in 2010. The level of poverty might grow even further in 2011 after the cuts in public spending; unprecedented austerity measures to counter Romania's public budget deficit, including a five-point increase in value-added tax (VAT), from $19 \%$ to $24 \%$, as well as a $25 \%$ wage reduction right across the public sector, will speed up this process. These measures, together with the effects of the economic crisis in the European Union, which will have an impact on remittances to Romania, threaten to plunge vulnerable and impoverished families even deeper into poverty; and a large percentage of working people are not immune to this threat.

The change in VAT is expected to generate severe increases in the prices of food, fuel and basic necessities and to decrease the level of consumption; producers say that this will have an impact on, or bankrupt, several businesses in the food and agriculture industries. In addition to the tax increases and wage reductions, the government plans to cut state benefits for disadvantaged categories of people (maternity leave allowance, unemployment allowance, the allowance that personal carers (of people with disabilities) receive, etc.). Significant reductions in the number of civil servant jobs have also been announced, with more than 100000 jobs expected to be cut by the end of the year.

In 2009, a study entitled Romania - a rapid assessment on the impact of economic crisis on poverty, published by UNICEF and the World Bank, anticipated that the economic crisis and recession would most probably lead to an increase in the number of children living in absolute poverty - from 256000 to approximately 350000 children - while the number of people living in absolute poverty would reach 1.6 million (i.e. $7.4 \%$ of the population). The report also states that $75 \%$ of these children would be from rural areas, under the age of 14 and from families with three or more children. Before 1990, child allowance was an important tool for balancing a family's income and it was the equivalent of 10 per cent of the average wage. The allowance was maintained after 1990, but its quantum dropped to less than half. At the moment, child allowance is 43 lei, not even ten per cent of the minimum wage. The study also shows that a family with two children, reliant on two minimum wages, is likely always to be facing severe poverty. More precisely, they will have to manage on 50 per cent of the minimum income needed for decent living.

Before 1989, children living in public institutions had been in the worst situation; afterwards, however, the reform of the child protection system, together with much better funding, has succeeded in improving the living conditions of many of them. A 
new problem has emerged instead - children living in poverty in their own families and children living alone as a result of the huge economic migration in recent years, a phenomenon which we shall describe later.

The prognosis made by UNICEF and the World Bank also states that the growing recession in EU countries, which is affecting the major sectors in which Romanians work abroad (construction and agriculture), would decrease the flow of funds transferred from abroad to Romanian families living in the country. Previously, this stood at around five to six per cent of the country's GDP.

This will affect the well-being of Romanian emigrants' families, including the well-being of the significant number of children left in the country.

Regrettably, the outcomes have shown that the prognosis was correct.

All these statistical data describing poverty are useful for our understanding; nevertheless, we cannot avoid noticing, as sociologists, the strange image of the reality that we have, based on the different instruments that we use to assess the situation. The absolute poverty indicator (used by World Bank or UNICEF) has decreased since 2001 (except during the period of crisis, when it started to rise again). However, relative poverty has increased continuously. It is a fact that, for many years, absolute poverty has been higher than relative poverty; the theoretical consequence of this is clear and paradoxical - somebody is living in absolute poverty, on less than $\$ 3$ per day, without being considered (relatively) poor. This theoretical paradox can be found in many poorer countries with large income inequalities between its citizens.

However, these considerations concerning statistics do not change the real social situation. Such a situation has to be dealt with through coherent policies, for both social and economic reasons. Reducing income inequality and poverty may expand and stabilise consumer demand, increase the investment of poor people in education and heighten workers' motivation and workplace co-operation, speeding up recovery.

Usually, we consider the share of total social spending within GDP as a general measure of the efforts of the state at producing a more equitable society. If that is true, Romanian governments have taken few responsibilities in this respect during recent years; public social spending registers a very low level compared to other EU member states, representing only $12.8 \%$ of GDP (ranking $25^{\text {th }}$ out of 27 , just behind Estonia and Latvia). The European Union average is more than double. Romania spent $€ 741$ per inhabitant on social protection in 2007 (before the crisis and austerity measures), while Denmark spent $€ 11570$ and Hungary, which is closer to Romania and with which it shares a similar recent history, spent $€ 1927$.

Legislative measures are also important in the achievement of a more equitable society. Romania's Labour Code has been assigned a special role in addressing the issue of poverty and a more correct distribution; more specifically, the provisions therein which are related to the guaranteed payment of a national minimum wage. Another important tool in tackling poverty is the guaranteed minimum income, enshrined by Law No. 416/2001. Both measures can be legally considered as assuring sufficient social protection for low-skilled working people or for those who have no job. A scrutiny of the content, however, provides another perspective. Currently, the 
minimum gross wage is 600 lei monthly, i.e. around $€ 140$, according to variations in currency exchange rates, while the minimum net wage is approximately $€ 100$. The guaranteed minimum income for a single person is 125 lei $(€ 26)$ per month and can achieve the level of the net minimum wage for a family of five who do not have any other means of earning a living (approximately $€ 100$ ). These levels are minimal indeed and can neither assure a living, nor act as incentives/disincentives to work; instead, they are a strong incentive to leave the country.

However, Romania does not have a culture of assessing public policies; for this reason, it is quite difficult to speak about their success or their malfunction. Despite the criticism levelled at it as being a disincentive to employment, the guaranteed minimum income must have contributed to the rapid reduction in absolute poverty after 2000. We may suppose that remittances from abroad have been another reason for this decrease. The figure for relative poverty has already shown that the growth in GDP during this period has had no significant direct input, as a result of the increasingly unequal distribution of growth.

There are two tendencies in Romanian social policy-making that inhibit the better results of such policies owing to the lack of an overview: i.e. the accumulation of many different small measures; and their regular modification. The main social benefits which have been established make up a long list, including the allowance for new-born children; children's allowance; incentives for parents who, although benefiting from parental leave, choose to resume work; complementary family allowance; support allowance for single-parent families and foster family allowance; the newly-weds support programme, including a unique contribution of $€ 200$ upon marriage; the home heating allowance programme for the cold season; etc. Up to seven million people are, apparently, beneficiaries. The situation creates the false impression that those in need enjoy strong public support via the receipt of many social benefits, but each separate public institution deals with its own beneficiaries, so the government has no concept of the overall situation - how many are the beneficiaries and how much each of them receives in social support. In order to overcome this difficulty and manage all social benefits in a unitary manner, a new institution has been set up - the National Agency for Social Benefits, of which results are expected in the future.

The inadequate amount of social expenditure is not the only problem; the concrete aspects of each policy implementation show a limited capacity to resolve the problems each one was created to resolve. The social benefits, such as they are, take a monetary form since the government and the municipalities have failed to create and provide the required social services. Therefore, beneficiaries receive a small amount of money and they must then buy the services they need from the free market; in this way, the results are quite limited. For example, there is a very poor network of public, affordable childcare services for children under three years old; and a baby-sitter or a private solution is too expensive, even for those earning a medium wage. The consequence is that women are practically forced to leave the labour market for a long time, losing skills and promotion opportunities, or abandon the idea of giving birth to a child.

Many doubts are also related to the social programmes which are focused on children living with their families not least since there are no guarantees that parents use the monetary support they receive to improve their children's lives; this is the main 
weakness cited by those who reject the idea of a guaranteed minimum income and condemn it as stimulating laziness.

An intermediate conclusion is evident; efforts have to be made to improve social policies when limitations have been noticed in their drafting or implementation; while an appropriate definition of the issue they are intended to resolve is essential. However, the difficulties we face in having more effective social policies should not justify the argument that, by doing nothing, we cannot make mistakes. The costs of such a choice are undermining the economy and society as a whole.

\section{The case of the trade-off in employment policy}

A society without unemployment is not a utopia at all; an ethical plan for erasing unemployment is a government obligation.

Amartya Sen

The country's development over the past twenty years, as described by the evolution of GDP, has been a sinuous one, characterised by two successive w-shaped trends and a long-lasting recovery after the big economic decline of the early 90 s when GDP decreased by more than $40 \%$; the 1989 level was regained only in 2004. The economic reforms which have been implemented have radically modified the work-related structure of the population: the number of employees was more than 8.2 million in 1990 , the majority of them working in industry; today, it is officially less than five million. Meanwhile, the number of pensioners has increased by two million, another two or three million have left the country looking for a job in the European Union or elsewhere; and the number of independent workers and freelancers is surprisingly high.

Companies operating at the beginning of the transition period have been restructured (based on the strict selection of the most profitable activities and on drastic cuts in personnel) and later privatised; many of these companies were subsequently shut down by the new owners (old competitors of those firms in the market). Other activities have been abandoned on account of there being no market, with no attempts whatsoever at privatisation. The number of people dismissed from their jobs is extremely high in both situations; the Romanian economy has had a limited capacity to resolve unemployment.

New companies have been established, with several notable exceptions, in miserably-paid fields of work, with jobs of poor quality and no prospects. For a decade or so, most jobs have been created in the garment industry; the populations of small- and medium-sized towns have survived due to the work of thousands of new employees most of them women - in this industry, which provided up to $40 \%$ of Romanian exports at the beginning of 2000 . These factories have been set up as a consequence of a western de-localisation process concerning labour-intensive activities; suppliers of raw materials have also provided opportunities for 'sell-offs' in western markets. Therefore, the long-term sustainability of these activities depends on two factors:

a) maintaining a labour force at a very low price in order to avoid a new de-localisation towards the 'east of the east' (Ukraine, Moldova, etc.)

b) the capacity of western markets to buy these products. 
EU accession and the economic crisis have generated significantly decreased demand which the internal market is not capable of replacing. The GDP crash at the beginning of the $90 \mathrm{~s}$, the liberalisation of prices and rapid inflation have drastically reduced purchasing power and, therefore, the economy's absorption capacity; it has slowly and gradually started to recover, but Romanian companies now have to deal with competition from imported products which are cheaper or of better quality. The impoverished part of the population is used to buying cheap Chinese products, while the new rich prefer European markets for their consumption purchases. Domestic manufacturers face obvious difficulties, with consequences for their ability to maintain existing jobs or to create new ones.

This is also quite obvious with the excessive dependency of the construction sector on public investment. Building companies manage to become prosperous and job-providing in one of two ways - where they sign contracts with public authorities (central or local) to build schools, hospitals, etc; or where they work as sub-contractors for bigger foreign companies that have outsourced their labour-intensive activities. There is not a sufficiently powerful internal market to secure their viability; therefore, the labour market registers an emphasised insecurity as far as the maintenance of jobs is concerned.

The pressure on industry was followed by a phenomenon of the rapid de-professionalisation of the skilled labour force. In this process, some people re-oriented themselves towards professions that were very different from those in which they had skills and experience; engineers belonging to the old socialist industries turned themselves into service suppliers - insurance policy agents; cosmetics sales representatives; or clerks.

In order to reduce the pressure on the labour market, the authorities in the middle of the $90 \mathrm{~s}$ decided on the premature retirement of workers who had practically no employment opportunities on account of their age and the lack of jobs. Some of these 'young' pensioners, as well as a significant part of those impoverished by the loss of better-paid industry jobs, left the towns, subsequently generating a unique phenomenon: that of the reversal of the urbanisation phenomenon of the $60 \mathrm{~s}$ and $70 \mathrm{~s}-$ the re-ruralisation of Romania. Almost $47 \%$ of the Romanian population live in rural areas where employment is almost non-existent. Their only alternative was to find a job abroad. Romanian labour migration became a widespread phenomenon in the postcommunist period. Over one-third of Romanian households (approximately 2500000 ) had at least one person working abroad after 1989. Labour migration intensified after 2002, given the new Schengen regulations, and, in 2006, labour migration was three times that of 2002.

After this, statistics on the migration of labour, which had been becoming a way of escaping poverty for many, were no longer kept. Receiving countries may have better data on immigration, but a first, striking issue for Romanian governments is that no institution or organisation has (for a long time) tried to approximate the number of people working abroad; three million people seems today to be the most correct estimate.

For a few years, governments presented the phenomenon as a political success, referring to it as 'freedom of movement'; that many other Europeans enjoy this freedom 
and do not leave in such high numbers provides grounds for a reconsideration of the issue. What does 'freedom to move' in Europe actually mean for workers? At least three conditions have to be accomplished:

a) to have rights and opportunities in their own countries and to choose to go abroad

b) to be allowed to enter another country's labour market when they need it

c) to be able to come back home when they want.

How could we explain in appropriate economic terms the fact of Romanian people working in another European member state in the circumstances we have just described? It seems more appropriate to speak of the constraint of leaving the country than of the freedom to move throughout Europe. The phenomenon is not at all new. The old phenomenon was called 'brain drain'. Given recent awareness of demographic challenges and of the value of human resources, this current 'brain' and 'hand' drain has even worse effects than before: Romania is now facing huge difficulties concerning its further development as a result of this drain of human resources. The government offers evidence that it has not yet realised the danger of pushing down wages. A new wave of migration is expected.

The remittances which have entered the country during the last few years have helped many poor families survive; this was a short-term solution with obvious effects - three million fewer contributors to the social security system; more difficulties in paying pensions because of the dramatic change in the ratio between employee contributors and retired people; the necessity of developing new social services to support children left at home in order to avoid both dropping-out of school and the danger of anti-social behaviour; and that qualified and experienced people finding opportunities and leaving has had, as a main result, lower productivity and a poorer quality of the goods and services provided at home; etc. We cannot find a good plumber anywhere, be it a Romanian or even a Polish one.

The long-term consequences are not yet apparent, but we can predict at least two. Many people work abroad without a legal contract and, as a consequence, have no social security; this category, the less-skilled one, will return in the future and increase the burden on an already-stretched social assistance system. The second category, highly-skilled professionals, will not come back at all, as many studies have already revealed. In spite of this worrying social situation, migration has reduced the pressure on the labour market; unemployment is less of a concern; and domestic demand has diminished.

The main problem for the government continues to be unemployment; all governments concur on this and Romania is not an exception. Creating enough jobs for those willing to work is still an unachieved goal - it is a bigger factor than making jobless people take-up vacant opportunities. The real economic deficit of the labour force generally occurs only in specific areas of activity, regions or periods; but, on the contrary, the population is forced to leave their homes because they lack job opportunities. If this is the case, two questions require an answer:

1. Is the government able to offer sufficient jobs for all those willing to work and what should be done in order to achieve this objective (dividing work; creating new jobs - in which fields and through which means, etc.)? 
2. Is there an authentic desire to create jobs for everyone, or is the jobless category necessary for the functioning of the current economic orthodoxy?

For many years, both political decision-making and scientific social research have used a few ready-made ideas and concepts that have actually prevented governments from achieving better results in combating unemployment. Artificial causal relations have been imagined in order to 'prove' the new ideologies. For example, many have used Denmark as an example of the positive results of 'flexibility', stating that a deregulated labour market explains Danish economic and social success; therefore, the assumption is that many other economic winners will emerge as a result of the multiplication of de-regulated markets.

The explanation of Danish achievements is quite different and it concerns human and institutional relations, not the content of legal provisions or the absence of such legal provisions on the labour market. Denmark did not regulate the labour market in an excessive manner, because it is useless to do so. Its society was built on everyone's rights and duties, as well as on mutual respect. Trust between the social partners is higher than elsewhere and verified through agreements that have been respected for more than a century; and confidence among the citizens is one of the highest in the world. It is not about sticks, in Denmark; it is about carrots. Moreover, in Denmark there are legal provisions guaranteeing high unemployment benefits $(90 \%$ of the person's previous income) for a very long period which can attain a maximum of four years out of six. The feeling of personal and economic security makes employment change easier; losing one's job is not such a catastrophic event as it is in Romania, where employment benefit is paid for a much shorter period (between nine and fifteen months) and the general amount is $75 \%$ of the minimum wage, together with a bonus of $3-10 \%$ of previous income, according to the number of years of contributions. Additionally, the lack of new opportunities puts the jobless in an even more precarious position.

The OECD has strongly promoted a composite index of the strictness of employment protection legislation as an instrument with which to enforce the idea that flexibility would reduce unemployment. In spite of the efforts which have been made, a correlation between the level of employment protection legislation and the reduction of unemployment cannot be sustained. Unfortunately, the labour market is not an autonomous market; there is a total dependence, in fact, on other markets and on the jobs provided by the public sector; nobody hires a new employee disregarding the level of demand for goods and services. There has been a fall in demand-generated unemployment in the United States, even though its employment protection legislation is one of the lowest in the world; meanwhile, many European countries have succeeded in better managing the situation in spite of having stricter legislation (Montousse, 2008).

Many political decisions based on academic research studies have also insisted on under-scoring the role of active measures in diminishing unemployment. The importance of active labour market policies is real, but it is not as high as we are used to thinking. In the short-run, these are truly useful for the faster take-up of existing jobs since they have only a marginal effect on reducing unemployment; actually, it is a statistical solution, not an economic one, as long as during training programmes those involved are no longer considered to be unemployed. In the long-run, the approach 
might be more effective were new jobs to appear and were employment services adequately to have anticipated the future needs of the market, suitably targeting their activity.

Another aspect about which we may be dubious is the practice of referring to social contributions as a simple burden and not as a part of security protection and, therefore, as a part of everyone's salaries. Cutting contributions is currently seen as a means of reducing labour costs and also unemployment. There are no concrete obligations for employers to create jobs when cutting social contributions so, whenever such policies have been implemented, the results have been deceptive - neither the price level has decreased nor has the number of jobs increased, at least not so far as to justify the effort. This is another piece of evidence for the weak link which exists between labour costs and employment. In Romania, the number of those earning the minimum wage has almost doubled during the past ten years, while the number of employees has remained constant. Moreover, the informal economy has not decreased at all.

Certainly, we may notice different concerns according to the different possible perspectives - employees; employers; working people; the jobless; or active or retired people. Amartya Sen and other thinkers have been trying to persuade us for a long time already that it is important to place these diverse concerns within a comprehensive assessment so that unemployment may not be treated as a reason for doing away with reasonable conditions of work for those who are already employed. At the same time, neither should the protection of existing employed workers be used as an excuse to keep the jobless in a state of social exclusion from the labour market and from employment.

The need for trade-offs is often exaggerated, and is typically based on very shortsighted reasoning. Furthermore, even when trade-offs have to be faced, they can be more reasonably - and more justly - addressed by the taking of an inclusive approach which balances competing concerns than by simply giving full priority to one group over another. Proceeding as Romania has done - defending competition at the risk of increasing exclusion - could have higher costs for society and could undermine economic efficiency more than we could usually accept, based on the arguments laying behind a few trendy theories.

\section{The case of the trade-off in education}

Education is an important area of concern due to the role that it plays in a country's social economic life. Rising employability and human resources' growing value on the labour market are only the direct quantifiable effects; improving a person's sense of well-being, increasing vertical mobility in society, strengthening social capital and, more generally, establishing a rising social status are some of the other aspects which are strongly related to a good education.

In Romania, as everywhere, the employability of educated people is higher than the capacity of finding a job for those who are less skilled; the explanation of a generally lower unemployment rate for this category of people comes from their having access to information, better health, richer social capital and the other characteristics that are usually linked to having a good education; moreover, it comes from their ability to accept offers of lower-skilled jobs when labour market demand is inappropriate for 
their professional level and skills; upside-down mobility is frequent. It has often been the case for Romania during the transition that researchers, engineers and other highlyskilled persons have agreed to work in areas where their competences are irrelevant, instead of not having a job at all. For the labour market's current rules, such a situation seems to be progress as long as higher employability and mobility are featured. Another perspective might, however, reveal it to be a misuse of human capital and an ineffective spending of public money, given their former level of education.

Equal and affordable education for all, disregarding income or age, is a vital condition for the country's progress as well as for economic efficiency. We believe that a better society has the following characteristics: equality of opportunity; limited income inequalities; the capability to deliver sustainable development; the fostering of human capital, creativity and innovation; security; social security and solidarity; social capital and trust; respect for the environment; and a civil democratic society. For all these features, people's education is a necessary pre-condition.

Unfortunately, instead of defending some areas of social life - such as education against the ravages of market forces, successive governments have not even started the struggle; on the contrary, they have seen privatisation as a solution for the improved functioning of the education system; this attitude has resulted in the exclusion of those who have no money to pay, as well as in an unexpected decrease in the quality of education. What a short-term perspective can justify in terms of competition and efficiency, a long-term perspective can totally reject; what works in one field does not work in another one at all. This rule has been ignored when many decisions concerning education have been taken. Education has been a field for incomplete but permanent reforms, each government having many good intentions but very poor results.

Nowadays, almost everybody who is able to pay taxes is able to obtain a higher education degree; the biggest university in the word is a Romanian one (300 000 students in 2009); this has provided the market with people having many diplomas but less of the skills required.

Of course, compulsory public education exists in Romania, as do public education institutions at any level. Unfortunately, education structure is a mirror of the societal structure, as social sciences have warned us over a long period. Income inequalities are reflected in inequalities in education. Poor people who live in rural areas or in poor urban districts are used to sending their children to schools that are less well-equipped to provide a good education; many face hard economic limitations to be able to send their children to school at all. The consequence is that a real poverty trap is emerging, across many generations. Only $1-2 \%$ of current students in universities come from families living off agricultural activities in rural areas and only $5 \%$ from rural areas in general.

Attempts to raise employability through active measures, such as the organising of training and lifelong learning, face strange and regrettable situations as a result of the effects of poverty. For example, one particular training programme failed, even though it was well-targeted and well-funded, and was required by the labour market, because insufficient people with primary school level were found among the jobless in need; poverty had made these young people drop out from the education system before graduating from compulsory primary school. In other words, illiteracy prevented them from 
attending the training course and from increasing their chances of employment. The real inequalities are always more profound than those on the surface.

The advice of teachers is very useful in order to reduce early drop-out behaviour; however, it could sometimes be simpler even than this. The most successful programme for improving school attendance among poor children, especially Roma children, has been the provision of a bread roll and some milk every day for every child in primary school. In spite of criticisms of this programme, after eight years laptele şi cornul (milk and a bread roll) has left a realistic example of what good looks like when drafting policies; better nourishment and better school attendance for children are equally important and have long-term consequences.

Different assessments of the Romanian education system have actually failed to provide a clear picture because of the lack of vision of the wider perspective. A few conclusions are, nevertheless, disturbing: there is a continually-increasing lack of trust in the education system; the confidence that education, in general, can ensure personal progress is very low; a large majority of students in universities wants to leave the country immediately after graduation; managers do not wish to organise workplace training courses any longer because, after acquiring the needed skills, many workers look for a job abroad and leave the country... Meanwhile, the very low monthly salary is, of course, one explanation for their leaving, as well as the low levels of efficiency.

\section{Conclusions}

When discussing social policies, we have to disconnect two different problems and, as a consequence, two different approaches:

a) the effectiveness of social policies

b) the effects on economic efficiency of having/not having social policies.

Social policies have to be conceived to target real needs and to maximise their effects. We could have poor social programmes (with restricted access and little money) but bringing relatively good results, as evaluated through the reduction of poverty and exclusion after the transfer has been made. We could notice a worse situation, when the little money is spent ineffectively - the administration costs are too high; the selection of the social target is not appropriate; implementation is sub-standard; or, frequently, there has been a misinterpretation of the problem that the administration has to cope with.

There are reasons to suppose that the economic effects of social welfare policies may be considerably less detrimental than assumed by the trade-off thesis; we consider that they are beneficial for both economic and social reasons. Reducing income inequality may expand and stabilise consumer demand, increase poor people's investment in education and heighten worker motivation and co-operation. In Romania, higher social expenditure would have prevented the human resource drain; for many, a good education for their children or better healthcare provision have constituted the decisive reason in their decision to leave the country. Meanwhile, constant attention paid to social protection during the transition would have avoided the country going into economic recession as deeply, via a strengthening of domestic demand and a limiting of the very high dependence on external markets. 
Furthermore, expansive social security programmes may enhance the flexibility of firms in labour deployment, facilitating labour mobility where this is necessary. In addition, social services could become a significant source of new jobs, helping the country to absorb especially female unemployment.

A job for all is a sensitive goal for each government because having a job - and a quality and satisfactory one - clearly defines a person's status; losing a job means losing not only income but status as well. A human being is a social animal whose self-respect is tied to status; for this reason, inequality and long-term unemployment have many practical implications. Poor or jobless people feel incapable of earning their living, or having a life; this causes depression and generates the adoption of bad behaviours such as alcoholism, drug use and criminality. These behaviours are clearly undermining for overall economic efficiency; moreover, the government cannot 'save money' by maintaining inequality and exclusion; less redistribution does not necessarily result in lower expenditure on social services, as what is not spent on reducing inequalities ends up being spent on dealing with their results (for example crime, drug treatments, healthcare).

The eastern European countries, but especially Romania, have to pay attention to human development and spend a greater part of their revenue on this purpose; investing more in cohesion policies could be a balanced solution for dealing with both goals higher efficiency as well as a more equitable society.

\section{References}

Artus, P and M-P Virard (2010) Pourquoi il faut partager les revenus La Découverte.

Bihr, A and R. Pfefferkorn (2008) Le système des inégalités La Découverte.

Cremers, J (2010) Non-Standard Labour Relations or the Erosion of Worker's Rights Solidar.

Cretu, G (2008) Mobility - between right and constraint Solidar conference.

Decade Watch Romania (2010) Evaluarea intermediara a decenului de incluziune a romilor.

Démier, F (1996) Istoria politicilor sociale Institutul European.

Fouarge, D (2003) Costs of non-social policy Report DG EMPL, European Commission.

Gazon, J (2007) Ni chômage, ni assistance L'Harmattan.

International Labour Review 139(2) (2000) 'Social Policy and Social Protection' special issue, available at: http:/www.ilo.org/public/english/revue/sommaire/ 139-2.htm.

Les Econoclastes (2004) Petit bréviaire des idées reçues en économie La Découverte.

Kenworthy, L (1998) Do social welfare policies reduce poverty!? Luxembourg Income Study.

Montousse, M (Ed.) (2008) 50 débats sur le travail Bréal. 
Ministerul Muncii si Protecției Sociale Raportul Național Strategic privind Inclusiunea Sociala şi Protecția Sociala 2008/2010.

Paugam, S (2007) Repenser la solidarité PUF.

Peña-Casas and Latta (2004) Working Poor in the European Union European Foundation for the Improvement of Living and Working Conditions: Brussels.

Platis, M (2008) Economia sectorului public, Eficiența şi echitatea sistemelor economice http://ebooks.unibuc.ro/StiinteADM/platis/cuprins.htm.

Stanculescu, M Harta saraciei in Romania, ICCV, http://www.iccv.ro/oldiccv/romana/ dictionar/manu/manu_harta.htm.

Stanculescu, M. S and I. Berevoescu (Eds.) (2004) Sarac lipit caut alta viața. Fenomenul saraciei extreme si al zonelor sarace in Romania Nemira: Bucureşti.

Stiglitz, J, A. Sen and J-P. Fitoussi (2009) Vers de nouveaux systèmes de mesure Odile Jacob.

Stiglitz, J (2010) Le triomphe de la cupidité LLL.

Viruela, M. R (2006) Inmigrantes rumanos en España: aspectos territoriales y procesos de sustitución Scripta Nova.

Zamfir, C, I. Stanescu and S. Ilie, S (2010) Dupa 20 de ani: Optiuni pentru Romania ICCV.

\section{Data sources:}

Eurostat, INS, World Bank, ICCV, MMPS, OECD. 